\title{
PERANCANGAN SISTEM INFORMASI MONITORING MAGANG
}

\section{DESIGN INTERNSHIP MONITORING INFORMATION SYSTEM}

\author{
H D Yulianto ${ }^{1}$, R B Firdaus ${ }^{2}$ \\ ${ }^{1}$ Departemen Komputerisasi Akuntansi \\ ${ }^{2}$ Departemen Sistem Informasi \\ Universitas Komputer Indonesia, Bandung \\ Email: hery.dwi.yulianto@email.unikom.ac.id
}

\begin{abstract}
Abstrak
Tujuan dari penelitian ini adalah merancang sebuah sistem informasi untuk menggantikan sistem pelaporan absensi mahasiswa dan pelaporan kegiatan harian mahasiswa magang yang selama ini masih dilakukan secara konvensional menjadi sistem yang terkomputerisasi sehingga keseluruhan proses dan pengelolaan informasi dapat berjalan dengan baik. terpusat. Metode yang digunakan dalam penelitian ini adalah metode deskriptif, dimana metode ini pada dasarnya menggambarkan secara akurat keadaan di lokasi penelitian. Hasil dari penelitian ini menghasilkan suatu rancangan sistem informasi terkomputerisasi baru untuk menggantikan sistem konvensional yang saat ini berjalan, dimana sistem informasi ini meliputi aplikasi website dan aplikasi mobile. Dengan teknologi GPS, lokasi siswa yang tepat akan diperoleh saat siswa melaporkan kehadirannya dan menanyakan alasan jika siswa melaporkan kehadirannya bukan di lokasi magangnya, sehingga memungkinkan pengawas untuk memantau siswanya lebih teliti. Kesimpulannya, merancang sistem informasi pemantauan magang dapat membantu proses magang dengan menghilangkan banyak aktivitas konvensional dan membuat informasi lebih terpusat. Hasil penelitian ini akan menjadi acuan untuk membangun sistem informasi monitoring magang yang diharapkan dapat membantu mempermudah proses magang.
\end{abstract}

\section{Kata Kunci: Monitoring, System, Application, Magang}

\begin{abstract}
The purpose of this research is to design an information system to replace the student attendance reporting system and student's intern daily activity reporting, which is still being done in a conventional way to be a computerized system so that the overall process and management of information is centralized. The method used in this research is descriptive. This research produces a design of a new computerized information system to replace the conventional system that is currently running, where this information system includes website and mobile applications. With GPS technology, the student's exact location will be obtained when the student reports their attendance and fill in information, not in their intern location. It allows the supervisor to monitor their student more thoroughly. In conclusion, designing an intern monitoring information system could help the internship process by removing lots of conventional activity and making information more centralized. The following research results will become a reference to build the intern monitoring information system, which is expected to facilitate the internship process.
\end{abstract}




\section{Keyword: Monitoring, System, Application, Internship}

\section{PENDAHULUAN}

Peningkatan kualitas pengelolaan dan pemantauan siswa berbasis teknologi di Indonesia kini menjadi kebutuhan dan perhatian di dunia pendidikan. Di bidang pendidikan, khususnya lembaga sekolah, bertugas melaksanakan proses pengelolaan pengajaran, kepegawaian, muri dan, keuangan, serta hubungan sekolah dengan masyarakat. Dalam hal hubungan sekolah dengan masyarakat, ada program magang untuk memfasilitasi proses tersebut. Program magang adalah program sekolah yang memungkinkan siswa untuk memiliki pengalaman situasi kerja di lingkungan profesional selama belajar di sekolah [1]. Program magang memberikan sumber pengalaman yang sempurna dalam kerja praktek, bekerja sama dalam tim, memoles portofolio, dan memperluas hubungan profesional di industri [2]. Sebagian besar industri lebih memilih untuk mempekerjakan lulusan yang berpengalaman, program magang dapat membantu siswa selangkah lebih dekat untuk mengamankan tempat kerja impian mereka [3]. Program magang dapat mengisi gap antara soft skill yang diperoleh di sekolah dengan hard skill yang dibutuhkan oleh industri [4]. Permasalahan yang dapat terjadi pada program magang adalah pelaporan absensi dan kegiatan harian masih belum terdokumentasi dengan baik dan masih dilakukan secara konvensional, sehingga menyulitkan pengawas untuk memantau kehadiran siswa dan aktivitas sehari-hari, siswa sering melupakan aktivitas sehari-hari dan kesulitan membuat laporan magang. Pemantauan magang dapat dilakukan dengan memanfaatkan layanan sistem informasi. Sistem informasi monitoring magang adalah suatu sistem yang membantu supervisor untuk memonitor mahasiswa magang baik kehadirannya, maupun aktivitasnya seharihari selama masa magang. Mengingat setelah masa magang berakhir, mahasiswa wajib membuat laporan magang dan mempresentasikannya pada uji coba magang. Sistem informasi harus dapat memberikan informasi tentang kehadiran mereka, dan kegiatan sehari-hari mereka sehingga mahasiswa dapat mengisi laporan magang mereka sesuai dengan informasi yang diberikan oleh sistem informasi. Akan lebih baik jika sistem informasi dapat mengekspor data absensi dan aktivitas harian ke dalam format laporan magang.

Terdapat beberapa penelitian terdahulu mengenai sistem monitoring magang, salah satunya penelitian yang dilakukan oleh Anif dkk dengan merancang sistem monitoring magang berbasis web [5]. Jaafar et al melakukan penelitian serupa dengan yang disebutkan sebelumnya, merancang sistem pemantauan dan pengawasan magang berbasis web [6]. Ayu dkk juga melakukan penelitian dengan merancang sistem informasi berbasis web untuk mengelola data magang [7]. Semua penelitian yang disebutkan sebelumnya mampu memberikan kebutuhan untuk melakukan prosedur magang, tetapi beberapa bagian yang hilang dalam kedua penelitian tersebut. Tidak ada penelitian sebelumnya yang menggunakan teknologi mobile seperti Android dan iOS. Dalam hal pengawasan, pengawas harus dapat benar-benar menemukan di mana siswa mereka melaporkan kehadiran mereka dan harus dapat memantau apakah siswa mereka melakukan pekerjaan mereka di industri atau tidak. Oleh karena itu, dalam penelitian ini, penulis bermaksud untuk merancang 
suatu sistem informasi yang mengisi semua bagian yang hilang.

Tujuan dari penelitian ini adalah merancang sebuah sistem informasi untuk menggantikan sistem pelaporan absensi mahasiswa dan pelaporan jurnal harian magang mahasiswa yang masih dilakukan secara konvensional menjadi sistem yang terkomputerisasi sehingga keseluruhan proses dan pengelolaan informasi terpusat. Metode yang digunakan dalam penelitian ini adalah metode deskriptif, dimana metode ini pada dasarnya menggambarkan secara akurat keadaan di lokasi penelitian. Metode penelitian yang digunakan penulis adalah metode penelitian kualitatif. Data yang dikumpulkan dalam penelitian ini berupa kata-kata atau gambar sehingga tidak terlalu menekankan pada angka. Penulis perlu memahami makna di balik data yang diamati dalam penelitian ini.

\section{LANDASAN TEORI}

\section{A. Perancangan}

Perancangan adalah kemampuan untuk membuat, mendesain atau membangun beberapa alternatif pemecahan masalah dengan membuat sistem baru $[8,9]$.

\section{B. Sistem Informasi}

Sistem Informasi mencakup beberapa komponen seperti manusia komputer teknologi informasi, dan prosedur kerja yang melakukan pemrosesan data menjadi informasi untuk mencapai suatu sasaran atau tujuan [10].

\section{Magang}

Magang atau internship merupakan kegiatan untuk menuangkan ilmu yang telah dipelajari dan mempraktekan kemampuan diri untuk memperoleh pengalaman kerja guna persiapan yang mendatang [11].

\section{Perancangan Sistem Informasi Monitoring Magang}

Desain atau rancangan untuk memberikan solusi laporan pemagangan dengan beberapa prosedur kerja dengan melibatkan teknologi informasi untuk melakukan monitoring dan membuat laporan pemagangan bagi pengguna laporan.

\section{METODE PENELITIAN}

Pengumpulan data sangat berpengaruh dalam penelitian. Karena data yang terkumpul dengan baik dapat menghasilkan sistem atau program yang berkualitas tinggi. Untuk metode pengumpulan data, penulis menggunakan teknik observasi dan wawancara. Penulis mengumpulkan data melalui observasi dan tinjauan menyeluruh secara langsung di lokasi Sekolah Menengah Kejuruan Negeri 4 Bandung. Wawancara langsung dilakukan penulis dengan Wakil Kepala Bidang Hubungan Internasional di Sekolah Menengah Kejuruan Negeri 4 Bandung. Dokumen yang digunakan dalam penelitian ini adalah dokumen laporan magang yang berisi informasi tentang tempat mahasiswa magang, kegiatan sehari-hari mahasiswa selama masa magang, dan penilaian mahasiswa magang oleh pembimbing lapangan.

Pendekatan berorientasi objek merupakan metode pendekatan yang digunakan penulis dalam penelitian ini. Masalah didefinisikan berdasarkan objekobjek yang ada dalam sistem. Cara ini 
sangat fleksibel sehingga mudah untuk mengubah program jika diperlukan.

Metode pengembangan Scrum merupakan metode pengembangan yang penulis gunakan dalam penelitian ini. Dalam scrum, pengiriman produk perangkat lunak dilakukan secara terus menerus secara iteratif, dalam waktu yang telah ditentukan sekitar 30 hari yang disebut sprint. Proses scrum diawali dengan visi mengenai produk yang akan dibangun dan berdasarkan visi tersebut dibuat daftar fitur produk dengan prioritas masing-masing yang disebut product backlog. Kemudian tim akan mengerjakan job description yang telah ditentukan pada sprint backlog [12]. Seluruh sprint dapat divisualisasikan seperti yang dijelaskan pada gambar 1 .

Gambar 1. Scrum Framework

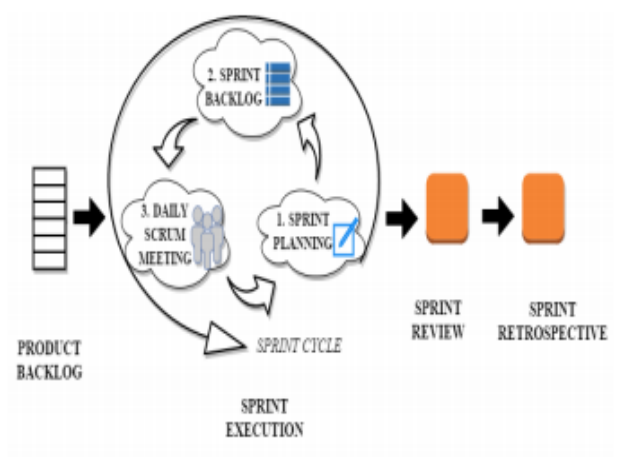

ANALISA SISTEM BERJALAN

Sistem yang berjalan saat ini terdiri dari 6 use case diantaranya Penugasan Magang, Magang Mahasiswa, Kunjungan Magang oleh dosen pembimbing, Pengisian Kegiatan Harian oleh mahasiswa, Penilaian Kerja Praktek oleh dosen pembimbing lapangan, dan Pembuatan Laporan Praktek Kerja oleh mahasiswa. Diagram use case akan dijelaskan pada gambar 2 .

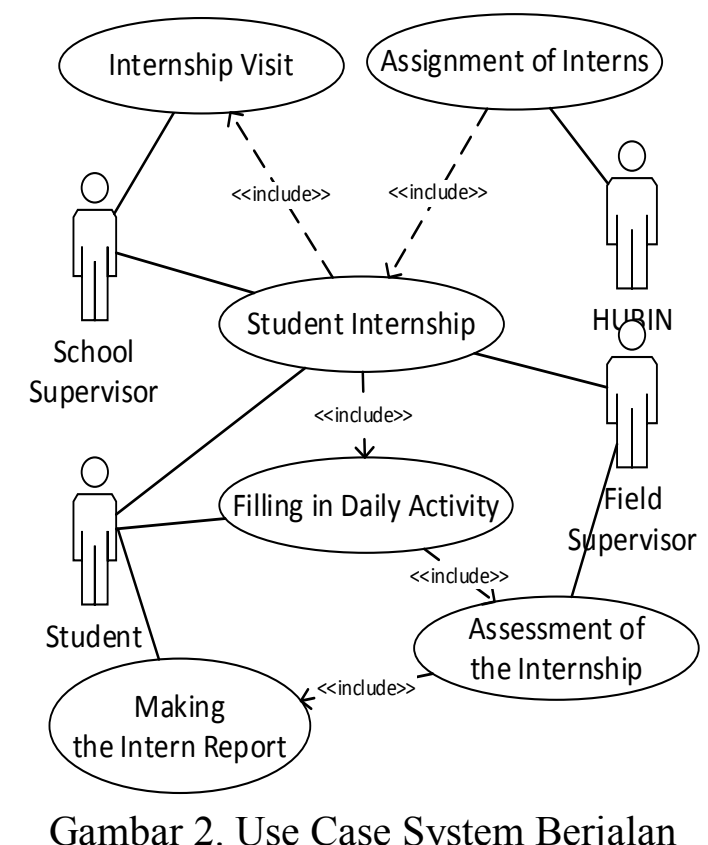

Berdasarkan use case di atas, siswa akan ditugaskan ke perusahaan oleh HUBIN. Kemudian mahasiswa akan memulai program magang dengan pergi ke perusahaan dan melakukan pekerjaannya di perusahaan tersebut. Sebulan sekali pengawas sekolah akan mengunjungi perusahaan untuk memantau siswa mereka. Setiap hari mahasiswa harus mengisi jurnal kegiatan harian yang akan dinilai oleh pembimbing lapangan pada akhir masa magang. Setelah masa magang berakhir, mahasiswa akan membuat laporan magang yang akan dipresentasikan pada uji coba magang. Sistem yang berjalan saat ini belum efektif dalam mengelola data magang karena masih dilakukan secara manual dengan menulis di atas kertas.

\section{PERANCANGAN SISTEM USULAN}

Sistem yang diusulkan terdiri dari 2 aplikasi yaitu aplikasi web dan aplikasi mobile. Aplikasi web akan dioperasikan oleh administrator sekolah untuk menginput data master meliputi data jurusan, data tahun akademik, data kelas, 
data siswa, data pengawas, dan data user. Pengelolaan data magang akan dilakukan pada aplikasi web seperti penginputan data perusahaan dan penugasan mahasiswa magang. Diagram use case dari aplikasi web akan dijelaskan pada gambar 3 .

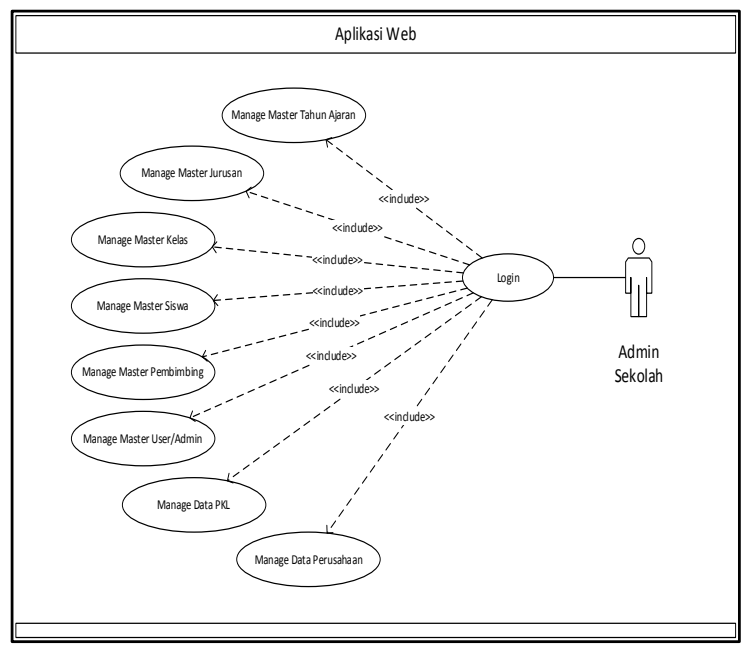

Gambar 3. Use Case Diagram Sistem yang Diusulkan untuk Aplikasi Web

Aplikasi mobile akan dioperasikan oleh siswa dan pengawas sekolah. Di sisi aplikasi siswa, siswa memulai dengan mengaktifkan akun mereka dengan kode unik mereka, mengatur kredensial akun mereka, dan kemudian masuk ke akun mereka. Setelah login, mahasiswa dapat melaporkan kehadirannya, mengisi aktivitas hariannya, melihat rekapitulasi kehadiran dan aktivitasnya, mengisi shift kerja, dan mengekspor data kehadiran dan aktivitasnya ke dalam format laporan magang. Sedangkan untuk aplikasi sisi pengawas, pengawas memulai dengan login ke akun mereka yang disediakan oleh administrasi sekolah. Setelah login, supervisor dapat melihat rekapitulasi kehadiran dan aktivitas siswanya, mengkonfirmasi aktivitas siswa sehari-hari. Baik siswa dan pengawas dapat mengubah profil akun dan kata sandi mereka. Diagram use case dari aplikasi mobile akan dijelaskan pada gambar 4 .

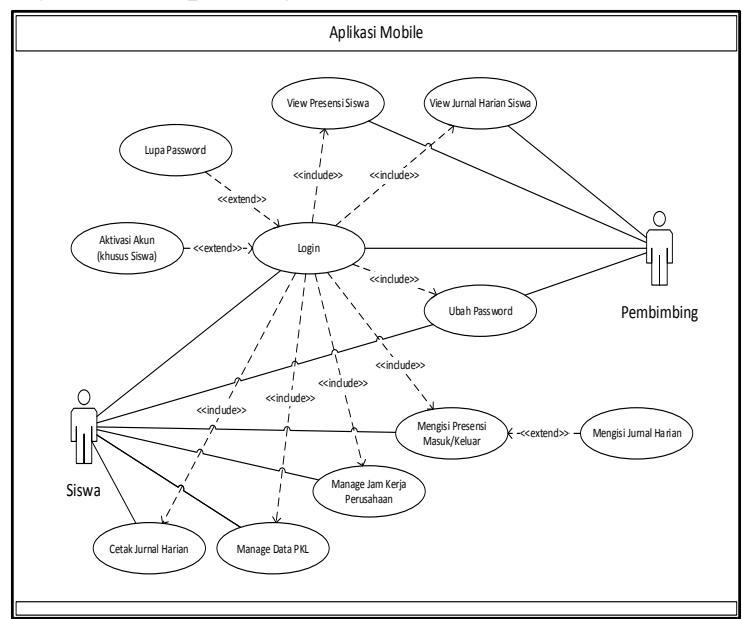

Gambar 4. Kasus Penggunaan Sistem yang Diusulkan untuk Aplikasi Seluler

Aplikasi mobile akan dibangun dengan Flutter SDK, Software Development Kit, dan mobile User Interface framework untuk membangun aplikasi hybrid dalam satu basis kode untuk platform yang berbeda seperti web, mobile (Android \& IOS) Windows [13]. Dengan menggunakan Flutter SDK, aplikasi mobile terdiri dari dua platform, antara lain Android dan iOS. Sistem pelaporan kehadiran akan menggunakan teknologi GPS yang merupakan sistem navigasi satelit [14-16]. Hal ini untuk mendapatkan lokasi yang tepat di mana siswa membuat laporan kehadiran mereka dan menanyakan mengapa seorang siswa melaporkan kehadiran mereka tidak di lokasi magang mereka, memungkinkan seorang guru untuk memantau siswa mereka secara menyeluruh. Antarmuka pengguna untuk aplikasi seluler ditunjukkan pada Gambar 5-6. 


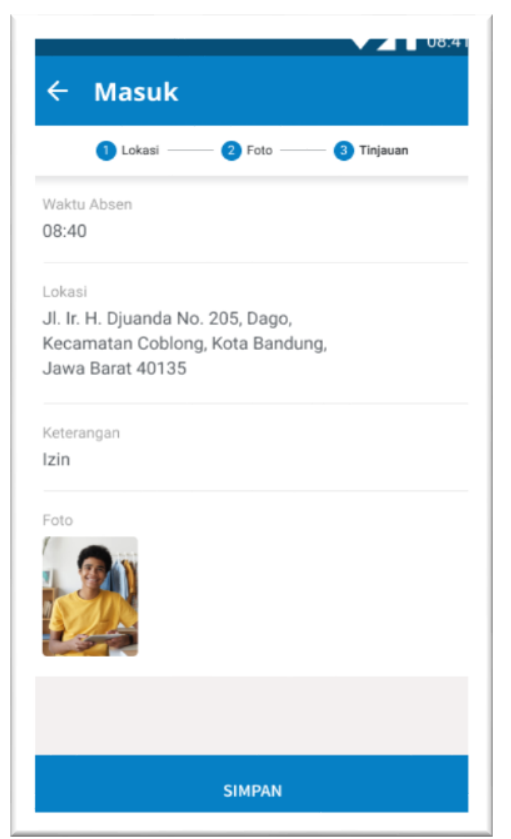

Gambar 5. Formulir Absensi Siswa \& Formulir Kegiatan Harian Siswa

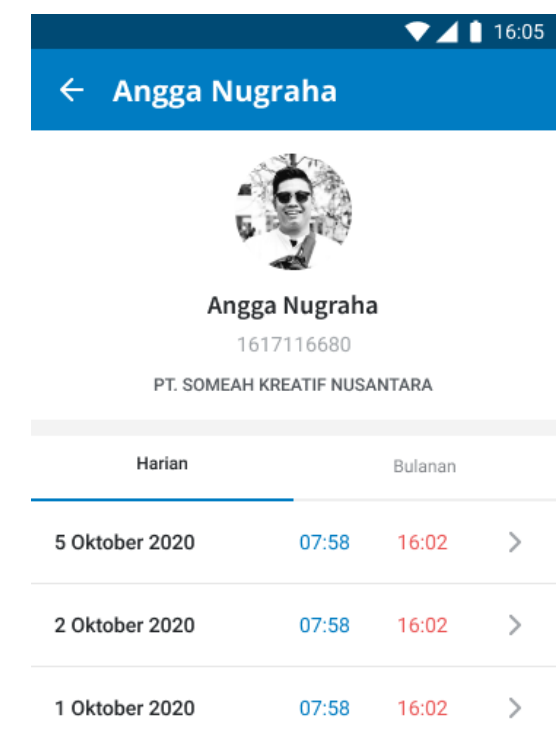

Gambar 6. Keluaran Laporan Absensi Siswa \& Keluaran Laporan Kegiatan Harian Siswa

\section{KESIMPULAN}

Setelah dilakukan penelitian dan pengembangan sistem informasi monitoring magang, penulis menyimpulkan bahwa. Dengan dibangunnya sistem informasi monitoring magang ini diharapkan dapat membantu proses pelaksanaan magang untuk meningkatkan kualitas program magang yang dilaksanakan oleh mahasiswa. Metode pengembangan yang digunakan dalam pengembangan sistem informasi manajemen magang ini dan fitur-fitur yang telah diterapkan diharapkan dapat membantu mempermudah pengembangan selanjutnya.

\section{DAFTAR PUSTAKA}

[1] Francis, R. S., \& Alagas, E. N. 2017. Satisfaction towards internship sprogrammes and future career development for students in private higher education institutions: A research note. Asia-Pacific Journal of Innovation in Hospitality and Tourism, 6(2), pp. 69-74.

[2] Anjum, S. 2020. Impact of internship programs on professional and personal development of business students: a case study from Pakistan. Future Business Journal, 6(1), pp. 1-13.

[3] Karunaratne, K., \& Perera, N. 2019. Students' perception on the effectiveness of industrial internship programme. Education Quarterly Reviews, 2(4).

[4] Patacsil, F. F., \& Tablatin, C. L. S. 2017. Exploring the importance of soft and hard skills as perceived by IT internship students and industry: A gap analysis. Journal of Technology 
and Science Education, 7(3), pp. 347-368.

[5] Anif, M., Dentha, A., \& Sindung, H. W. S. 2017. Designing internship monitoring system web based with Laravel framework. In 2017 IEEE International Conference on Communication, Networks and Satellite (Comnetsat) (pp. 112-117). IEEE.

[6] binti Jaafar, A. N., binti Rohafauzi, S., bin Mohd Fauzi, F. D. H., \& bin Amron, M. T. 2017. Development of internship monitoring and supervising web-based system. In 2017 IEEE 15th Student Conference on Research and Development (SCOReD) (pp. 193197). IEEE.

[7] Ayu, F., \& Permatasari, N. 2018. Perancangan Sistem Informasi Pengolahan Data PKL (Praktek Kerja Lapangan) Di Devisi Humas Pada PT Pegadaian. Jurnal Intra Tech, 2(2), pp. 12-26.

[8] H. D. Yulianto dan D. F. Maulana, "Perancangan Sistem Informasi Akuntansi Persediaan Barang DagangBerbasis SAKEMKM,"@is Best Account. Inf. Syst. Inf. Technol. Bus. Enterp., vol.5, no. 2, hal. 121-135, 2020.

[9] D. W. Firdaus dan S. Febryan, "Perancangan Sistem Informasi Akuntansi Harga Pokok Produksi Pada Distro Viking Cimahi Dengan Menggunakan Software Microsoft Visual Basic 2008 Dan Database MySQL," @is Best Account. Inf. Syst. Inf. Technol. Bus. Enterp., vol.4, no. 1, pp. 366380, 2019.
[10] A. Kadir. 2014. Pengenalan Sistem Informasi. Yogyakarta. Andi.

[11] M. Y. H. Setyawan dan A. S. Munari. 2020. Panduan Lengkap Membangun Sistem Monitoring Kinerja Mahasiswa Internship Berbasis Web dan Global Positioning System. Bandung. Kreatif Industri Nusantara.

[12] Sharma, S., \& Hasteer, N. 2016. A comprehensive study on state of Scrum development. In 2016 International Conference on Computing, Communication and Automation (ICCCA) (pp. 867872).

[13] Allain, H. 2020. Improving productivity and reducing costs of mobile app development with Flutter and Backend-as-a-Service.

[14] Hegarty, C. J. 2017. The global positioning system (GPS). In Springer Handbook of Global Navigation Satellite Systems (pp. 197-218). Springer, Cham.

[15] Mulyana, A., Rusmana, D., \& Rafdhi, A. A. 2021. Application platform for e-reservation system in traditional show. In Journal of Physics: Conference Series (Vol. 1764, No. 1, p. 012197).

[16] Singgih, I, K. 2020. Air Quality Prediction in Smart City's Information System. International Journal of Informatics, Information System and Computer Engineering. 1(1), pp. 36-47. 